\title{
CORNELL
}

Rehabilitation Research and Training Center for Economic Research on Employment Policy for Persons with Disabilities

\section{Policy Brief:}

Policies and Programs

Affecting the Employment of

People with Disabilities

Prepared by

Cornell University

\section{The Lewin Group}

Gina A. Livermore

Mark W. Nowak

David C. Wittenburg 
For further information about this paper contact:

Gina A. Livermore, Ph.D.

Cornell Center for Policy Research

1779 Massachusetts Ave., NW, Suite 820

Washington, DC 20036

Phone: (202)518-3388; Fax: (202)518-3352; email: GAL23@cornell.edu

This paper is being distributed by the Rehabilitation Research and Training Center for Economic Research on Employment Policy for Persons with Disabilities at Cornell University.

This center is funded to Cornell University, in collaboration with The Lewin Group (Falls Church, VA), and The Urban Institute (Washington, D.C.) by the U.S. Department of Education, National Institute on Disability and Rehabilitation Research (cooperative agreement No. H133B980038).

This research is funded by the U.S. Department of Education, National Institute on Disability and Rehabilitation Research (cooperative agreement No. H133B980038). It does not necessarily reflect the view of the National Institute on Disability and Rehabilitation Research.

The Co-Principal Investigators are:

Susanne M. Bruyère - Director, Program on Employment and Disability, School of Industrial and Labor Relations, Extension Division, Cornell University

Richard V. Burkhauser - Sara Gibson Blanding Professor and Chair, Department of Policy Analysis and Management, College of Human Ecology, Cornell University

David C. Stapleton - Director, Cornell Center for Policy Research, Cornell University 


\section{Policies and Programs Affecting the Employment of People with Disabilities}

Prepared by:

Cornell University

The Lewin Group

Gina A. Livermore

Mark W. Nowak

David C. Wittenburg

\section{August 2000}

For more information on the Cornell RRTC contact:

Susanne Bruyère, Ph.D.

Project Director

Cornell University

106 ILR Extension Building

Ithaca, NY 14853-3901

Tel (607) 255-7727

Fax (607) 255-2763

TDD (607) 255-2891

e-mailssmb23@cornell.edu

web www.ilr.cornell.edu/rrtc
Send comments on paper to:

Gina Livermore, Ph.D.

Vice President

The Lewin Group

3130 Fairview Park Dr., Suite 800

Falls Church, VA 22042

Tel (703) 269-5561

Fax (703) 269-5503

e-mail gina.livermore@lewin.com web www.lewin.com 


\section{INTRODUCTION}

The purpose of this brief is to summarize the wide range of federal programs and government policies that influence the employment and program participation decisions of people with disabilities and current research initiatives related to these programs and policies. The brief is organized by the following types of programs, policies, and initiatives:

- federal programs that provide cash assistance, in-kind transfers (e.g., health insurance) and education, training, and rehabilitation support based on disability status and/or other characteristics (e.g., family structure);

- federal tax policies that provide credits either directly to individuals with disabilities or to employers as an incentive to hire a person with a disability;

- other employment-related programs and public policies that provide accommodation support and work incentives for people with disabilities;

- recent policy changes that affect people with disabilities; and

- some of the current research initiatives related to federal programs, tax policies, other employment programs and policies, and recent policy changes.

We conclude with a summary of our program, policy, and research scan.

This publication is based on The Economics of Policies and Programs Affecting the Employment of People with Disabilities, which provides a more comprehensive review of the policies and programs discussed here (as well as others) and analyzes the employment effects of these policies and programs within an economic framework.

\section{GOVERNMENT ASSISTANCE AND SUPPORT PROGRAMS}

\section{A. Cash Assistance Programs for People with Disabilities}

A number of cash assistance programs exist to provide either temporary or permanent benefits to people who have experienced losses of income due to disabling physical or mental health conditions. These programs vary regarding eligibility as well as the extent to which they replace pre-disability earnings, and therefore vary in how, and to what extent, they influence the employment decisions of beneficiaries (Livermore, et al., 2000). The major programs include:

- Social Security Disability Insurance (DI). The purpose of the DI program is to replace a portion of lost income due to a worker's physical or mental disability. To qualify, an individual must meet the Social Security Administration's (SSA) definition of disability and be insured for disability through prior work experiences. To satisfy the disability criterion, an individual must (1) have a medically determined disability expected to last at least 12 months or result in death and (2) be unable to engage in substantial gainful activity (SGA). ${ }^{1}$

\footnotetext{
${ }^{1}$ SGA is currently defined as the equivalent of working at a job that pays $\$ 700$ or more a month.
} 
An individual is insured for disability if he or she has worked in a job covered by Social Security for a specified number of quarters (which varies by age). There is a five-month waiting period for benefits after the onset of a disability for those who are determined eligible for DI. DI beneficiaries are also eligible for Medicare coverage (discussed below) after a two-year waiting period from receipt of initial benefits. While the DI program includes several provisions that allow beneficiaries to maintain their eligibility for cash and/or Medicare benefits if they return to work, beneficiaries can lose DI and Medicare eligibility if earnings rise above the SGA level.

- Supplemental Security Income (SSI). The federal SSI program provides basic monthly income to people age 65 and older, to the blind, or to people of any age who meet SSA's definition of disability. Children under age 18 can qualify under certain child specific disability and income eligibility criteria. The major eligibility difference between the adult SSI and DI programs is that a person must satisfy a means and asset test to qualify for SSI benefits, whereas under DI they must meet certain past work history conditions. ${ }^{2}$ In addition, most SSI recipients are immediately eligible for Medicaid benefits (discussed below). Finally, SSI benefits are generally much lower than average DI benefits (\$388 vs. \$681 in December 1999). While the SSI program includes several provisions that allow recipients to maintain their eligibility for cash and/or Medicaid benefits if they return to work, they can lose a portion or all of their SSI benefit levels if they become employed and have earnings above a certain thresholds.

- Workers' Compensation (WC). WC programs provide cash benefits, medical care, and rehabilitation services for workers who suffer work-related injuries and diseases, and to some dependents of workers. WC programs are subject to certain state and federal regulations, though there is substantial variation in WC eligibility rules and benefits across states. Employers provide the funding for WC programs, and state-regulated insurance companies, employers who self-insure, or special state insurance funds distribute the benefits. WC benefit levels vary by state, but temporary or permanent total disability benefits are commonly set at two-thirds weekly earnings up to some maximum. Unlike SSI or DI, WC payments are available for partial disabilities (either temporary or permanent). It is important to note that, under certain conditions, workers with disabilities can qualify for both WC and DI. In general, WC payments are discontinued upon returning to work.

- Veterans Administration Programs. The Veterans Administration provides disability compensation to veterans who are discharged honorably and who have experienced or aggravated a disabling injury or disease during active military service. Veterans who have non-service related disabilities, or who are age 65 or older, are also eligible to receive a veteran's pension.

Several other state, employer, and individual programs also provide benefits to cover a loss of income due to disability. For example, Private Disability Insurance (PDI) is an employer sponsored or an individually purchased benefit that usually replaces 60 percent of earnings in

\footnotetext{
${ }^{2}$ It is important to note that some individuals might satisfy the income requirements of both SSI and DI and receive benefits from SSI and DI.
} 
case of a long-term disability. ${ }^{3}$ Five states have Temporary Disability Insurance (TDI) programs that provide cash benefits to certain workers to ensure against wage loss when an individual cannot work because of sickness or injury not caused by his/her job. ${ }^{4}$ The Black Lung benefit program, which is administered by the Department of Labor, provides disability benefits to miners and their families. Finally, some states have General Assistance (GA) programs that provide temporary benefits to adults with disabilities.

\section{B. Other Cash Assistance Programs}

In addition to participating in programs designed specifically to assist people with disabilities, people with disabilities might choose also to participate in other (non-disability) programs relevant to other circumstances and/or background characteristics. For example, some people with disabilities might apply to non-disability cash assistance programs because (1) they only need temporary assistance; (2) their limitation is not severe enough to satisfy the strict disability definitions of the above programs; and/or (3) they might be unaware or unwilling to apply for one of the aforementioned disability programs.

Unlike most of the disability programs described above, which provide long-term or permanent cash assistance, these other programs are designed to provide temporary cash assistance. The major programs include:

- Temporary Assistance for Needy Families (TANF). TANF is a federal-state program that provides cash benefits to low-income families with children. TANF is a state block grant program. Under TANF, states have flexibility to determine eligibility requirements and benefit levels, but benefits are subject to federal time limits and work requirements. ${ }^{5}$ The federal time limit is five years, though states can choose a shorter limit. Researcher have noted that TANF recipients with disabilities have a strong incentive to apply for SSI benefits because SSI payments are generally larger than those from TANF and SSI benefits are not time-limited. ${ }^{6}$

- Unemployment Insurance (UI). UI is a federal-state program that provides temporary and partial wage replacement to involuntarily unemployed workers who were recently employed. While UI eligibility rules vary across states, in general all workers must satisfy certain "monetary and non-monetary eligibility" requirements to be eligible for a weekly check. In general, to satisfy these requirements a worker must have: (1) worked in UI-covered employment (which includes most wage and salary jobs); (2) earned enough in his or her

\footnotetext{
${ }^{3}$ Insurers usually require their PDI beneficiaries to apply for DI.

${ }^{4}$ The five states include California, Hawaii, New Jersey, New York, and Rhode Island.

${ }^{5}$ The TANF work requirements are relatively complex, but, in general, states must place adult TANF recipients in work no later than their twenty-fourth month of assistance. TANF recipients who do not satisfy the work requirements are subject to either reduced benefits or benefit termination. States that do not meet certain participation requirements are subject to financial penalties.

${ }^{6}$ Further, state TANF offices might refer recipients to SSI to save state TANF dollars. Although an individual cannot receive benefits from TANF and SSI simultaneously, a family can. In almost all states, the income of a TANF family increases when a member of the family transitions to SSI (i.e., the new SSI payments more than offsets the reduction in TANF). Stapleton, et al (2000) found that a significant portion of Aid to Families with Dependent Children (the program that preceded TANF) recipients transitioned onto SSI before the enactment of TANF in 1996.
} 
base years to qualify for UI; and (3) was not terminated for cause. Employers generally pay unemployment taxes to cover the costs of unemployment benefits, which is deposited in a state UI trust fund (monitored by the Department of Labor).

\section{In-Kind Support}

Many participants in disability and other cash transfer programs also receive in-kind support from various sources. In-kind supports include any payments made to an individual in the form of a commodity or service. These supports, particularly health care coverage, can be very valuable to people with disabilities. The major in-kind support programs include:

- Medicare. Medicare is a national health insurance program that provides coverage to eligible persons over age 65 and certain populations of people with disabilities (most notably, DI beneficiaries). Medicare consists of the Hospital Insurance program (Part A) and Supplementary Medical Insurance Program (Part B). DI beneficiaries are automatically eligible for Part A (after a two-year waiting period). Part A provides coverage for inpatient hospital care, skilled nursing facility care, home health care, and hospice care. Part B, which is voluntary (i.e., those eligible must pay a premium to participate), provides coverage for doctor services, other medical and health services (e.g. X-ray and other therapy) and home health services.

- Medicaid. Medicaid is a federal-state matching entitlement program that provides a very important source of health benefits to low-income children and pregnant women, adults in families with dependent children, low-income persons with disabilities, and low-income elderly persons. Many individuals become eligible for Medicaid through their participation in transfer programs, such as SSI and TANF, though federal legislation in the early nineties expanded coverage to all children whose family income was below 100 percent of the federal poverty level. Optional and state-only programs significantly expand coverage to people with disabilities in some states. As discussed in more detail below, Congress recently enacted changes in the Ticket to Work and Work Incentives Improvement Act of 1999 that expands state options in the future to provide Medicaid coverage to people with disabilities.

- Food Stamps. The Federal Food Stamp program, which is administered by the Agriculture Department's Food and Nutrition Service, provides benefits to increase the food purchasing power of eligible low-income households. Specifically, Food Stamp benefits make up the difference between a participating household's expected contribution to its food costs and an amount judged to be sufficient to buy a nutritionally adequate low-cost diet. Benefits are available to most households that meet federal eligibility tests for limited monthly income and liquid assets.

- Assistive Devices and Technologies (AT). Several public policies and private funding sources either promote the (1) public accessibility or (2) individual use of AT devices. ${ }^{7}$ An assistive

\footnotetext{
${ }^{7}$ For example, the Telecommunications Act of 1996 requires that manufacturers and providers of telecommunications equipment and services make the equipment and services they provide usable by people with disabilities (e.g., audio amplifiers and ring signal lights). The Medicaid, Medicare, and State Vocational Rehabilitation (VR) programs all provide direct funding for different types of AT (e.g., durable medical equipment). The Assistive Technology Act of 1998 provides continuity grants for AT to states that have received fewer than 10 years of funding under the Technology-Related Assistance for Individuals with Disabilities Act of 1988. This act
} 
technology (AT) device is "any item, piece of equipment, or product system...used to increase, maintain, or improve functional capabilities of individuals with disabilities." ${ }^{8}$ Most AT devices help people with certain disabilities process information or by simplifying necessary work routines. Examples of AT include wheelchair lifts and telecommunication devices.

- Personal Assistance Services (PAS). Similar to AT, PAS is financed through both public programs and private sources (e.g., personal funding or employer accommodations). Publicly-financed programs (e.g., Medicare, Medicaid) that deliver PAS are typically designed and implemented at the state level, with substantial variability regarding service provisions and eligibility restrictions among programs. ${ }^{9}$ Examples of PAS include help from another person to accomplish with daily activities (e.g., bathing, cleaning, preparing meals), communication, transportation, and help completing job-related tasks.

- Supportive Housing for Persons with Disabilities. The Supportive Housing for Persons with Disabilities program, administered by the Department of Housing and Urban Development, provides interest-free capital advances to nonprofit organizations that build, rehabilitate, or purchase rental housing to be used as supportive housing for persons with disabilities. The advance is interest free and does not have to be repaid as long as the housing remains available for very low-income persons with disabilities for at least 40 years.

- Energy and Housing Assistance Programs. Two programs provide benefits that reduce the costs of housing and energy. The Low-Income Home Energy Assistance Program (LIHEAP), which is administered by the Administration for Children and Families within the Department of Health and Human services, makes grants available to states and other jurisdictions to help eligible households meet the costs of home energy. The Housing Choice Voucher program, administered by the Department of Housing and Urban Development, provides housing assistance payments to participating owners on behalf of eligible tenants.

\section{Education, Training, and Rehabilitation}

Multiple education, training, and rehabilitation programs provide support to help individuals become employed and self-sufficient. Unlike the programs described above that provide cash or

allows states the option of using grant money to increase funding for AT through state-financed systems. Finally, as discussed in more detail later in the paper, the Americans with Disabilities Act (ADA) requires that employers make reasonable accommodations for their employees.

${ }^{8}$ Assistive Technology Act of 1998.

${ }^{9}$ There are several examples of publicly funded PAS programs. For example, Medicaid, Social Service Block Grants (Title XX), Title III of the Older Americans Act, State funds, VA Aid and Attendants Allowance, and Medicare provide services based on need and income level. In addition, under Section 67(d) of the internal revenue code, impairment-related work expenses, including attendant care services at or in connection with the place of work, are tax deductible without regard to the threshold levels that ordinarily apply to the deduction for employee business expenses. Finally, in recent years, four states have introduced acts that provide funding for PAS for people with disabilities, usually by reallocating funds from nursing home expenditures (Vermont's Personal Assistance Services Act of 1996, the Ohio Community Assistance Services Act of 1996, Georgia's Long Term Care Choice Act of 1997, and the Community Attendant Services Act of Texas of 1997). Although these laws do not specifically target employed people with disabilities, they all share common features that might make it easier for users to enter the labor market. 
in-kind support, the education, training and rehabilitation programs primarily provide service support that focus on integrating people with disabilities into the labor market. Some of the major programs and policies include:

- Vocational Rehabilitation (VR). VR is a nationwide federal-state program that provides medical, therapeutic, counseling, education, training, work-related placement assistance, and other services. VR was established to provide the services and supports that a person might need to overcome a barrier to employment. People enter the VR system in a variety of ways. ${ }^{10}$ To be eligible for state VR services, a participant must meet certain criteria. First, he or she must have a physical or mental impairment that results in a substantial barrier to employment. Second, he or she must be able to benefit from VR services. Finally, he or she must be eventually able to achieve an employment outcome. State VR agencies can deny benefits if they can show that a person cannot benefit from the services. To make determinations, state VR agencies use existing data, such as medical reports, SSA records, and education records and, to the extent existing data is insufficient to determine eligibility, an assessment by the VR agency. While the state VR programs are the largest providers of rehabilitation services, there are also several other private VR programs that provide services to certain populations of people with disabilities.

- Education Programs and Policies. Under the Individuals with Disabilities Education Act (IDEA), states are required to provide free appropriate public education for students with disabilities at the elementary and secondary level. Schools are required to create Individual Education Programs (IEPs) to help assist youth with disabilities obtain important services at no additional cost to their families. IEPs identify available services and include plans for post-secondary transitions from school to work for secondary-school youth with disabilities. Most education programs for youth with disabilities also receive support from various other state and federal programs, particularly Medicaid, as well as grants from the US Department of Education, Office of Special Education (OSEP).

- Other Training Programs. People with disabilities who do not immediately contact the VR, SSI or TANF systems might gain access to training and employment services through a variety of other programs that receive state and federal funding. For example State Workforce Development Systems, organized under the Workforce Investment Act of 1998 (WIA), require states to develop workforce development plans that describe the state's plan for meeting the needs of individuals with disabilities and ensuring nondiscrimination and equal opportunity. The Projects with Industry Program (PWI), created by the Rehabilitation Act of 1973 and administered by the U.S. Department of Education, creates partnerships among business, industry, labor, and the rehabilitation community to assist in providing employment opportunities for people with disabilities. Finally, Independent Living Programs provide grants to states and nonprofit organizations to establish and support centers for independent living, which provide a number of employment-related services, including skills training.

\footnotetext{
${ }^{10}$ Some enter because of their participation in other programs (e.g., SSA VR Reimbursement Program). Others might enter because of their involvement with a particular organization (e.g., school). Finally, some enter the program on their own or because of a referral from a stakeholder. VR offices are generally located in close proximity to, or with, other state program offices, such as TANF, and in many states are coordinated with one-stop delivery systems.
} 


\section{FEDERAL TAX POLICIES}

The U.S. tax code includes several provisions that provide work incentives for people with disabilities. Individuals can take advantage of these incentives by claiming exemptions on payroll taxes and/or by taking the exemption at the end of the year when filing income tax returns. The major incentives include:

- Itemized Deduction of Impairment-Related Work Expenses (IRWE). Any worker with a limitation may deduct impairment-related work expenses (IRWE) from his or her taxable income. Deductible expenses include those necessary for the satisfactory completion of work, those for goods and services not required or used in personal activities, and those not specifically covered by other tax laws.

- Earned Income Tax Credit (EITC). The Earned Income Tax Credit (EITC) is targeted to lowwage earners, supplementing the earnings of such workers through a refundable income tax credit. The income limits that determine eligibility for this credit are more generous for people with children. ${ }^{11}$

- Income Exemption of Flexible Health Care Spending Accounts. The Income Exemption of Flexible Health Care Spending Accounts allows individuals to exclude health care expenses from taxable income, up to a maximum benefit of $\$ 3,600$ per year. These accounts may be used to pay for most health care expenditures.

The government also provides tax incentives for businesses to hire people with disabilities. The general purpose of most of these taxes is to lower the cost of employing people with disabilities. For example, some tax incentives might offset higher costs associated with accommodating a person with a disability in the workplace. The major business tax incentives include:

- Section 190 Deduction. The Section 190 Deduction, also called the Deduction of Costs of Removing Architectural or Transportation Barriers to the Disabled or Elderly, allows businesses to deduct expenses incurred while removing from the premises physical barriers to persons with disabilities.

- Section 44 Credit. The Section 44 Credit, also known as the Disabled Access Credit, is a non-refundable tax credit for small businesses that pay or incur expenses to provide access to persons with disabilities, such as for compliance with the Americans with Disabilities Act (ADA).

- The Work Opportunity Tax Credit (WOTC) and Welfare to Work Credit. The Work Opportunity Tax Credit (WOTC), enacted in August 1996, grants employers a tax credit equal to 35 percent of the wages of certain targeted groups, including persons with physical or mental disabilities. ${ }^{12}$

\footnotetext{
${ }^{11}$ A panel of experts convened by the National Academy of Social Insurance (NASI) has recommended supplementing the earnings of people with disabilities directly through a Disabled Worker Tax Credit (DWTC).

${ }^{12}$ The passage of the Welfare-to-Work Credit (WtWC) bolsters the value of this credit.
} 


\section{OTHER EMPLOYMENT-RELATED PROGRAMS AND POLICY INITIATIVES}

Many people with disabilities receive support from other employment related programs and policies that encourage employment and equal access to services by either prohibiting discrimination and/or by creating networks of supports. These programs and policies include:

- Americans with Disabilities Act. The Americans with Disabilities Act of 1990 (ADA) is regarded as one of the most important legislative initiatives that protects people with disabilities from discrimination This Act prohibits job-related discrimination against people with disabilities, and requires that reasonable accommodations be provided by employers for people with disabilities. The Act also prohibits state and local governments from discriminating against people with disabilities in employment practices, and in excluding people with disabilities from participating in or receiving benefits of programs, services or activities. The Act requires that all public and private transportation services be accessible to all people, including public accommodations (such as restaurants, movie theaters, museums, malls, etc.) Finally, the Act requires telecommunication carriers to increase availability of interstate and intrastate telecommunications relay services.

- Job Accommodation Network. The Job Accommodation Network (JAN), a service of the President's Committee on Employment of People with Disabilities, is a toll-free information and referral service providing information on job accommodation, employers' responsibilities under the ADA, and on technical assistance, funding, education, and services related to the employment of people with disabilities.

- Project ABLE (Able Beneficiaries Link to Employers). Project ABLE is a national resume bank that provides employers an easily accessible applicant pool of qualified job-ready individuals who are interested in working. The resume bank operates through the joint efforts of the Office of Personnel Management (OPM), SSA, Rehabilitation Services Administration (RSA), the VA, and state VR agencies. The goal is to provide employers access to quality human resources, and training and employment services to eligible people with disabilities.

\section{RECENT POLICY INITIATIVES}

In recent years, several policy initiatives have directly modified or otherwise affected the programs and policies discussed in the previous sections. These changes either affect program eligibility, program benefits, and/or the availability of support to people with disabilities. The initiatives include:

- 1999 Ticket- to Work and Work Incentive Improvement Act (TWWIIA). TWWIIA includes five provisions - Ticket to Work and Self-Sufficiency Program, Expansion of Health Insurance Eligibility, Elimination of Other Work Disincentives, Demonstration Project on Change in DI Benefits Schedule, and Work Incentives Outreach Program - that feature work incentives to people with disabilities. The Ticket to Work and Self-Sufficiency Program will provide eligible DI beneficiaries with a voucher (i.e. ticket) to obtain VR or employment services. The Expansion of Health Insurance provisions are intended to reduce the cost of health care to people with disabilities who work. Specifically, these provisions loosen restrictions on states regarding who is eligible to buy into the Medicaid program, and provide 
for the continuation of Medicare coverage for individuals formerly receiving DI benefits. ${ }^{13}$ The Elimination of Other Work Disincentives provisions institute limitations on conducting continuing disability reviews (CDRs) for individuals using a Ticket to Work and it prohibits the use of work activity as a basis for review of an individual's disability status. The Demonstration Project on Change in DI Benefits Schedule provisions grants SSA the authority to evaluate the effects changing the working eligibility rules for DI beneficiaries. ${ }^{14}$ Finally, the Work Incentive Outreach Program provisions directs SSA to establish a community-based work incentive planning and assistance program, for the purpose of providing accurate information related to work incentives to beneficiaries with disabilities. ${ }^{15}$

- 1997 Balanced Budget Act. Section 4733 of the Balanced Budget Act (BBA) expands state options to provide Medicaid for working people with disabilities by creating a new optional eligibility category. Specifically, this legislation allows states to provide health insurance to individuals with incomes up to 250 percent of the federal poverty level. ${ }^{16}$ While SSI eligibility is not a requirement for this provision, states must make a disability determination to expand coverage to those not enrolled in SSI.

- 1998 Workforce Investment Act. Title I of the Workforce Investment Act (WIA) provides assistance to states interested in establishing statewide and local workforce investment systems to increase employment, retention and earnings of participants. The objectives of the WIA include improving the quality of the workforce to sustain economic growth, improving productivity and competitiveness, and reducing dependency on welfare. Under the WIA, states are required to write workforce development plans describing how the state plans to meet the needs of major customer groups, including individuals with disabilities, and show how the plans will ensure nondiscrimination and equal opportunity. Of particular importance for people with disabilities is that WIA mandates that one-stop systems be easily accessible to all Americans. All adults are eligible for core services and youth enrolled in school are eligible for certain services if they meet certain state criteria for employment, income, and/or disability. ${ }^{17}$

\footnotetext{
${ }^{13}$ In addition, these provisions allow workers with disabilities who have a "Medigap" policy - a commercial insurance policy that provides benefits that are supplemental to Medicare - to suspend the premiums and benefits of the Medigap policy if they have employer-sponsored coverage.

${ }^{14}$ Specifically, this provision gives SSA the authority to evaluate the effects changing the working eligibility rules for DI beneficiaries to allow DI beneficiaries to retain $\$ 1$ of benefits for every $\$ 2$ of earnings at a specified level.

${ }^{15}$ Under the program, SSA will establish a competitive program of grants, cooperative agreements, or contracts to provide benefit planning and assistance, including information on the availability of protection and advocacy services, to DI and SSI beneficiaries; conduct or fund ongoing outreach efforts; and establish a corps of work incentive specialists within SSA who specialize in DI and SSI work incentives for the purpose of providing accurate information. SSA will award grants for the outreach efforts based on a percentage of the population of disabled beneficiaries in the State. The total amount of all grants awarded will not exceed $\$ 23$ million in each fiscal year from 2000 through 2004.

${ }^{16}$ Oregon, Minnesota, Mississippi, South Carolina are currently using the buy-in, while Wisconsin and Alaska are planning to implement the buy-in in the near future. Ohio, California, New Mexico, North Carolina, and Oklahoma are seeking a waiver to expand Medicaid coverage. Finally, Colorado, Arkansas, and Utah are expanding health care insurance/services.

${ }^{17}$ All individuals who receive DI or SSI are automatically eligible under the WIA for VR services. In many states, these systems are directly linked to VR and/or TANF services. Core services include determinations of eligibility for
} 
- Presidential Task Force on Employment of Adults with Disabilities. The objective of The Presidential Task Force on Employment of Adults with Disabilities, established in March 1998 , is to create a coordinated and consistent national policy to bring adults with disabilities into productive employment at a rate close to that of the general adult population. The Task Force will develop and recommend to the President a coordinated set of policies to reduce employment barriers for people with disabilities. ${ }^{18}$

- Social Security Administration (SSA) and Rehabilitation Services Administration (RSA) State Partnership Initiatives. In 1998, SSA and RSA initiated several projects designed to improve services and programming for people with disabilities as they attempt to enter or reenter the workforce. Both agencies have awarded cooperative agreements to 17 states. Most of these grants aim to make it easier for people with disabilities to use existing services, via service integration or counseling. Most also include some form of continued health insurance coverage.

- Substantial Gainful Activity (SGA) Definition Increase to $\$ 700$. In July 1999, the definition of SGA was raised from $\$ 500$ to $\$ 700$ of earned income per month. The SGA threshold, the amount of income that an individual with a disability may earn without losing disability benefits, provides a significant incentive to work only up to the income level of the threshold. This adjustment is the first of its kind since 1990, reflecting recent growth in average wages.

- Department of Labor Office on Disability Policy, Evaluation, and Technical Assistance. The U.S. Department of Labor provides funding for a new Office on Disability Policy, Evaluation, and Technical Assistance, which will be charged with increasing the employment rate of people with disabilities. The office will guarantee that laws enforced by the department are evaluated to identify and remove any existing barriers for people with disabilities. Moreover, the office will confirm that all services of the new system of one-stop centers, established by the Workforce Investment Act, are accessible to people with disabilities.

\section{RESEARCH INITIATIVES}

Several government agencies, including the SSA, the Department of Education, and the Department of Health and Human Services, are sponsoring research efforts to better understand the factors that promote employment and economic independence among people with

\footnotetext{
assistance; intake and initial assessment services; job search, placement and career counseling; and provision of vocational rehabilitation services.

${ }^{18}$ The Task Force published its Second Annual Report to the President in November 1999. In the report, it reviewed progress toward objectives stated in the First Report and laid out new recommendations including the following: (1) Further integrating the efforts of various federal agencies including the Departments of Labor, Education, Justice, and Health and Human Services, the Social Security Administration, and the Office of Personnel Management; (2) improving the enforcement and increased utilization of already-existing legislation and further promoting the Federal government's role as a leader in the effort to increase employment among people with disabilities; (3) engaging in research to increase understanding of barriers to employment and to establish a reliable measure of the employment rate among people with disabilities; (4) developing and promoting the use of technology to make gainful employment more feasible for people with disabilities; and (5) promoting legislative efforts to make work more financially rewarding for people with disabilities.
} 
disabilities. Many of these efforts are examining the interaction of work with one or more of the programs described above. The major initiatives include:

- National Institute on Disability and Rehabilitation Research (NIDRR) Rehabilitation Research and Training Centers (RRTCs) on Employment. NIDRR recently established several new RRTCs aimed at improving employment outcomes of people with disabilities. All centers will conduct research, training, technical assistance, and dissemination activities. Examples of the topics addressed by the centers include issues specific to American Indians, training of persons with long-term mental illness, community rehabilitation programs to improve employment outcomes, economic research on employment policy for people with disabilities, educational supports, maintaining the employment status and addressing the personal adjustment needs of individuals who are hard of hearing or late deafened, personal assistance services (PAS), state systems and employment outcomes, workforce investment and employment policy for people with disabilities, and workplace supports.

- SSA National Study of Health and Activity (NSHA). The National Study of Health and Activity (NSHA), sponsored by SSA, is a national disability study of the American workingage population (aged 18-69). A pilot study will begin in 2000 and the main study, starting about a year later, will result in about 10,000 completed interviews for a nationallyrepresentative sample. The study will provide detailed information on individuals who may satisfy SSA's disability criterion for benefits.

- SSA Disability Research Institute. SSA is funding a cooperative agreement to create a Disability Research Institute (DRI) to address the need for more extensive research for policymakers, including information on SSA disability programs and VR services. The DRI is a university-based, multi-disciplinary center that will utilize a network of scholars from a variety of institutions.

- SSA Demonstration on the Treatment of Affective Disorders. SSA is designing a demonstration that will test the effectiveness of providing better access to quality treatments for affective disorders to DI beneficiaries whose primary reason for impairment is an affective disorder. Persons with affective disorders represent one of the fastest growing cohorts on the disability rolls, representing one in nine DI beneficiaries. The rationale behind the demonstration is that appropriate treatment for such disorders can be effective in anywhere from 60 to 80 percent of cases. This, combined with the fact that many beneficiaries lack access to adequate treatment (because of lack of health insurance, and high co-pays and deductibles and no prescription drug coverage under Medicare), suggests that providing access to treatment will result in improved health status of DI beneficiaries with affective disorders, and, in turn, lead to increased labor force participation and selfsufficiency. The demonstration is scheduled to begin around the end of fiscal year 2000 and will last for five years.

- ASPE Study of Employment Supports Used by Working People with Disabilities. This project will provide information to federal agencies, states, social service agencies, advocates for people with disabilities, and consumers with disabilities to develop and inform policies that will promote the employment of people with significant disabilities. The focus of this study is to identify, through interviews and focus groups, the supports and other factors that have 
been instrumental in allowing individuals with significant disabilities to become successfully employed.

\section{SUMMARY}

We provide a summary of our policy scan in the Appendix. This appendix provides a brief description and highlights the target population for each of the programs, policies, and research initiatives summarized above.

Despite the large number of programs and policies directed towards people with disabilities, there is no system that provides a universal source of benefits and services to this population. Rather, several government agencies administer programs that have their own eligibility rules. Some of these programs focus on returning people with disabilities to work, while others focus on providing income and other support not related to work. In many cases, people with disabilities are eligible for benefits and services from multiple programs. Consequently, many people with disabilities who (might) participate in these programs face complex incentives in deciding whether to enter the labor market.

It is important to note that this brief does not highlight the complex interactions that exist across programs and, more importantly, the potential impacts of these programs (and program interactions) on economic decisions of people with disabilities. Readers interested in these more complex economic consequences of these programs and policies should refer to Livermore, et al. (2000). In that report, , we highlight program work incentives and disincentives, program overlaps (e.g., Supplemental Security Income and Medicaid) and discuss the potential impact of these programs (and their overlaps with other programs) on the economic decisions of people with disabilities. This larger report should serve as a useful guide for researchers and policy makers interested in understanding and evaluating the economic consequences for people with disabilities of these programs and policies. 


\section{Appendix:}

Public Programs and Policies Affecting the Employment of People with Disabilities

\begin{tabular}{|c|c|c|}
\hline PROGRAMI POLICY/INITIATIVE & DESCRIPTION & TARGET POPULATION \\
\hline \multicolumn{3}{|c|}{ Public Income Support Programs Targeting People with Disabilities } \\
\hline Social Security Disability Insurance (DI) & $\begin{array}{l}\text { Program to insure workers against loss of income due to disability. Payments are based on } \\
\text { individuals' lifetime average earnings covered by Social Security. }\end{array}$ & $\begin{array}{l}\text { Adults with disabilities with sufficient DI- } \\
\text { covered earnings history }\end{array}$ \\
\hline Supplemental Security Income (SSI) & $\begin{array}{l}\text { Means-tested program to provide monthly cash income to people age } 65 \text { and older and those } \\
\text { under } 65 \text { who are blind or disabled. }\end{array}$ & $\begin{array}{l}\text { People age } 65 \text { and older, blind and } \\
\text { people with disabilities of any age with } \\
\text { limited income }\end{array}$ \\
\hline Workers' Compensation (WC) & $\begin{array}{l}\text { Cash payments, rehabilitation services and medical benefits provided by employers to } \\
\text { workers who suffer work-related injuries or diseases. }\end{array}$ & $\begin{array}{l}\text { People who suffer work-related injuries } \\
\text { and diseases }\end{array}$ \\
\hline Veterans Administration Programs & $\begin{array}{l}\text { Programs including disability compensation payments and veterans' pensions that provide } \\
\text { payments to people aged } 65 \text { or older or less than } 65 \text { and disabled who served in the military. }\end{array}$ & $\begin{array}{l}\text { Veterans of military service that are } \\
\text { over } 65 \text { or disabled }\end{array}$ \\
\hline \multicolumn{3}{|l|}{ Other Public Income Support Programs } \\
\hline $\begin{array}{l}\text { Temporary Assistance for Needy Families } \\
\text { (TANF) }\end{array}$ & Program that provides time-limited cash benefits to needy families with children. & Low-income families with children \\
\hline Unemployment Insurance & $\begin{array}{l}\text { Provides temporary benefits to workers who have recently lost their jobs, based upon their } \\
\text { earnings prior to unemployment. }\end{array}$ & Recently unemployed workers \\
\hline Medicare & $\begin{array}{l}\text { Public health insurance program for individuals age } 65 \text { and over and persons with disabilities. } \\
\text { The program provides both hospital coverage (Part A) and supplementary medical insurance } \\
\text { (Part B). }\end{array}$ & $\begin{array}{l}\text { People age } 65 \text { and older, current/former } \\
\text { DI beneficiaries }\end{array}$ \\
\hline Medicaid & $\begin{array}{l}\text { Federal-state matching entitlement program that provides medical assistance primarily to low- } \\
\text { income and otherwise needy individuals, including persons with disabilities. Eligibility may be } \\
\text { linked to SSI or TANF. }\end{array}$ & $\begin{array}{l}\text { Low-income children and pregnant } \\
\text { women, adults in families with } \\
\text { dependent children, people with } \\
\text { disabilities, and the elderly }\end{array}$ \\
\hline Assistive Technology Act of 1998 & $\begin{array}{l}\text { Provides grants to states that may be used to provide assistive technology devices to } \\
\text { individuals, as well as to increase public awareness of available assistive technology. }\end{array}$ & $\begin{array}{l}\text { People with disabilities in need of } \\
\text { assistive technology devices }\end{array}$ \\
\hline Personal Assistance Services (PAS) & $\begin{array}{l}\text { Services performed by a person to assist an individual with disabilities to accomplish the } \\
\text { basic activities of daily living (ADLs), including mobility, eating, and dressing. Other PAS } \\
\text { might include assistance with communication, transportation, and help completing job-related } \\
\text { tasks. }\end{array}$ & $\begin{array}{l}\text { People with disabilities in need of help } \\
\text { with activities of daily living (ADLs). }\end{array}$ \\
\hline Food Stamps & $\begin{array}{l}\text { Increase the food purchasing power of low-income households by subsidizing food purchases } \\
\text { through coupons that can be used like cash at the grocery store. }\end{array}$ & Low-income households \\
\hline The Housing Choice Voucher Program & $\begin{array}{l}\text { Combines the Section } 8 \text { Voucher and Section } 8 \text { Certificate programs, providing housing } \\
\text { assistance payments to participating owners on behalf of eligible tenants. }\end{array}$ & Low-income households \\
\hline
\end{tabular}


Appendix (continued):

Public Programs and Policies Affecting the Employment of People with Disabilities

\begin{tabular}{|c|c|c|}
\hline PROGRAM/ POLICY/INITIATIVE & DESCRIPTION & TARGET POPULATION \\
\hline \multicolumn{3}{|c|}{ Other Public Income Support Programs (continued) } \\
\hline $\begin{array}{l}\text { Supportive Housing for Persons with } \\
\text { Disabilities }\end{array}$ & $\begin{array}{l}\text { Provides interest-free capital advances to nonprofit organizations to build, rehabilitate, or } \\
\text { purchase rental housing to be used as supportive housing for persons with disabilities. }\end{array}$ & $\begin{array}{l}\text { Persons with physical or mental } \\
\text { disabilities }\end{array}$ \\
\hline $\begin{array}{l}\text { Low-Income Home Energy Assistance } \\
\text { Program (LIHEAP) }\end{array}$ & $\begin{array}{l}\text { Makes grants available to states and other jurisdictions to assist eligible households to meet } \\
\text { the costs of home energy. }\end{array}$ & Low-income households \\
\hline \multicolumn{3}{|l|}{ Education, Training, and Rehabilitation } \\
\hline $\begin{array}{l}\text { Individuals with Disabilities Education Act } \\
\text { (IDEA) }\end{array}$ & $\begin{array}{l}\text { Requires states to provide free and appropriate public education for students with disabilities } \\
\text { at the elementary and secondary level. }\end{array}$ & $\begin{array}{l}\text { Children and young adults with } \\
\text { disabilities. }\end{array}$ \\
\hline State Vocational Rehabilitation & $\begin{array}{l}\text { A federal-state program intended to help people with physical and mental impairments to } \\
\text { work by providing services including medical and therapeutic services, counseling, education, } \\
\text { training, and job placement assistance. }\end{array}$ & $\begin{array}{l}\text { Adults with physical or mental } \\
\text { impairments who are able to benefit } \\
\text { from VR services }\end{array}$ \\
\hline Veteran Vocational Rehabilitation & A program similar to the state VR program that provides services exclusively to veterans. & Veterans with service-related disabilities \\
\hline $\begin{array}{l}\text { State Workforce Development Systems } \\
\text { (Workforce Investment Act of 1998) }\end{array}$ & $\begin{array}{l}\text { Program mandated by the Workforce Investment Act of } 1998 \text { that requires states to integrate } \\
\text { job training, adult education and literacy, and VR programs into a one-stop delivery system. }\end{array}$ & $\begin{array}{l}\text { All adults, youth who meet state- } \\
\text { determined criteria }\end{array}$ \\
\hline Projects with Industry Program (PWI) & $\begin{array}{l}\text { Program that facilitates job placement for people with disabilities emphasizing job training in } \\
\text { work settings. Encourages partnerships among business, industry, labor, and the } \\
\text { rehabilitation community. }\end{array}$ & Adults with disabilities \\
\hline Independent Living Programs & $\begin{array}{l}\text { Provides grants to states and nonprofit organizations to establish support centers for } \\
\text { independent living, which provide independent living skills training, peer counseling, } \\
\text { community outreach and employment services. }\end{array}$ & People with significant disabilities \\
\hline \multicolumn{3}{|c|}{ 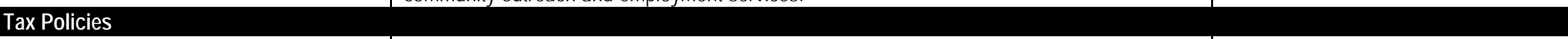 } \\
\hline $\begin{array}{l}\text { Income Exemption of Flexible Health Care } \\
\text { Spending Accounts }\end{array}$ & $\begin{array}{l}\text { A benefit that may be offered by employers and that allows employees to exclude up to } \\
\$ 3,600 \text { per year of their health care expenses from their taxable income. }\end{array}$ & $\begin{array}{l}\text { All employees of firms that offer the } \\
\text { benefit }\end{array}$ \\
\hline $\begin{array}{l}\text { Itemized Deduction of Impairment-Related } \\
\text { Work Expenses( IRWEs) }\end{array}$ & $\begin{array}{l}\text { Allows people with disabilities who work to deduct the cost of impairment related work } \\
\text { expenses (IRWE) from their taxable income. }\end{array}$ & $\begin{array}{l}\text { Persons with physical or mental } \\
\text { disabilities that limit ability to work }\end{array}$ \\
\hline Earned Income Tax Credit (EITC) & $\begin{array}{l}\text { Supplements the earnings of low-income workers by providing them with a refundable income } \\
\text { tax credit. }\end{array}$ & Low-income individuals \\
\hline Section 190 Tax Deduction & $\begin{array}{l}\text { Allows businesses to deduct expenses related to removing barriers or impediments to } \\
\text { persons with disabilities from their places of business. }\end{array}$ & All businesses \\
\hline Section 44 Tax Credit & $\begin{array}{l}\text { Tax credit intended to help cover the expenses incurred by small businesses to provide } \\
\text { access to people with disabilities. }\end{array}$ & Small businesses \\
\hline Work Opportunity Tax Credit & $\begin{array}{l}\text { Provides employers a tax credit equal to } 35 \% \text { of the wages of certain groups, including } \\
\text { people with disabilities. }\end{array}$ & Employers of targeted groups \\
\hline
\end{tabular}


Appendix (continued):

Public Programs and Policies Affecting the Employment of People with Disabilities

\begin{tabular}{|c|c|c|}
\hline PROGRAMI POLICY/INITIATIVE & DESCRIPTION & TARGET POPULATION \\
\hline \multicolumn{3}{|c|}{ Other Employment-Related Programs and Policies for People with Disabilities } \\
\hline Americans with Disabilities Act of 1990 & $\begin{array}{l}\text { Prohibits job-related discrimination against people with disabilities and requires employers to } \\
\text { provide "reasonable accommodations," which may include personal assistance services or } \\
\text { assistive technology devices. }\end{array}$ & All people with disabilities \\
\hline Job Accommodation Network (JAN) & $\begin{array}{l}\text { A service of the President's Committee on Employment of People with Disabilities, JAN is a } \\
\text { toll-free information and referral service that provides information on job accommodation, } \\
\text { employers' responsibilities under the ADA, and on technical assistance, funding, education, } \\
\text { and services related to the employment of people with disabilities. }\end{array}$ & All interested persons and employers \\
\hline Project Able & $\begin{array}{l}\text { Resume bank established specifically to match jobs to appropriately qualified people with } \\
\text { disabilities. }\end{array}$ & $\begin{array}{l}\text { Adults with disabilities who are "job- } \\
\text { ready" }\end{array}$ \\
\hline Balanced Budget Act of 1997 & $\begin{array}{l}\text { Gives states the option of allowing people with disabilities with incomes of up to } 250 \% \text { of the } \\
\text { federal poverty standard to buy-in to Medicaid if they are not otherwise eligible. }\end{array}$ & Low-income workers with disabilities \\
\hline $\begin{array}{l}\text { Presidential Task Force on Employment of } \\
\text { Adults with Disabilities }\end{array}$ & $\begin{array}{l}\text { Task force instituted to create a coordinated national policy to increase the employment of } \\
\text { people with disabilities. }\end{array}$ & All people with disabilities \\
\hline Workforce Investment Act of 1998 & $\begin{array}{l}\text { States are required to develop workforce development plans that describe how the state will } \\
\text { meet the needs of major customer groups, including individuals with disabilities, and show } \\
\text { how the plans will ensure nondiscrimination and equal opportunity. }\end{array}$ & $\begin{array}{l}\text { Major customer groups, including } \\
\text { people with disabilities }\end{array}$ \\
\hline $\begin{array}{l}\text { Social Security Administration (SSA) and } \\
\text { Rehabilitation Services Administration } \\
\text { (RSA) State Partnership Initiatives }\end{array}$ & $\begin{array}{l}\text { Grants to states to improve coordination of services and programming for people with } \\
\text { disabilities preparing to enter (or reenter) the workforce. }\end{array}$ & $\begin{array}{l}\text { Adults with disabilities (mainly SSI and } \\
\text { DI) }\end{array}$ \\
\hline $\begin{array}{l}\text { Substantial Gainful Activity (SGA) Increase } \\
\text { to } \$ 700\end{array}$ & $\begin{array}{l}\text { The change in the definition of substantial gainful activity from } \$ 500 \text { to } \$ 700 \text { is intended to } \\
\text { facilitate work for DI/SSI beneficiaries by reducing the chance that return-to-work efforts will } \\
\text { cause the immediate loss of cash benefits. }\end{array}$ & SSI and DI beneficiaries \\
\hline $\begin{array}{l}\text { Ticket to Work and Work Incentives } \\
\text { Improvement Act of } 1999 \text { (TWWIIA) }\end{array}$ & $\begin{array}{l}\text { The Act is intended to reduce work disincentives related to the SSI and DI programs. } \\
\text { Provisions include the ticket to work program, which provides vouchers for rehabilitation and } \\
\text { employment services, expanded Medicaid and Medicare eligibility, outreach to disseminate } \\
\text { accurate information about work provisions, demonstrations to study the effect of changing } \\
\text { the DI benefits schedule, and the elimination of other work disincentives. }\end{array}$ & $\begin{array}{l}\text { Primarily DI and SSI beneficiaries with } \\
\text { disabilities, and other low-income } \\
\text { people with disabilities }\end{array}$ \\
\hline $\begin{array}{l}\text { Department of Labor Office on Disability } \\
\text { Policy, Evaluation, and Technical } \\
\text { Assistance }\end{array}$ & $\begin{array}{l}\text { Office charged with increasing the employment rate of people with disabilities. The Office will } \\
\text { be headed by an assistant secretary and will absorb the President's Committee on the } \\
\text { Employment of People with Disabilities. }\end{array}$ & All people with disabilities \\
\hline
\end{tabular}


Appendix (continued):

Public Programs and Policies Affecting the Employment of People with Disabilities

\begin{tabular}{|c|c|c|}
\hline PROGRAMI POLICY/INITIATIVE & DESCRIPTION & TARGET POPULATION \\
\hline \multicolumn{3}{|l|}{ Research Initiatives } \\
\hline $\begin{array}{l}\text { National Institute of Disability Rehabilitation } \\
\text { and Research (NIDRR) Rehabilitation } \\
\text { Research and Training Centers (RRTC) on } \\
\text { Employment }\end{array}$ & $\begin{array}{l}\text { The National Institute of Disability Rehabilitation and Research sponsors a number of } \\
\text { rehabilitation research and training centers (RRTCs) that conduct research and training in } \\
\text { different areas related to improving the employment outcomes of people with disabilities. }\end{array}$ & $\begin{array}{l}\text { All people with disabilities (the specific } \\
\text { population focused on varies by center) }\end{array}$ \\
\hline National Study of Health and Activity & $\begin{array}{l}\text { SSA sponsored study to better understand the relationship between disability and work, } \\
\text { family, community, and access to health care. Approximately } 10,000 \text { people with } \\
\text { impairments will be interviewed. }\end{array}$ & All people with disabilities \\
\hline SSA Disability Research Institute & $\begin{array}{l}\text { SSA will fund an institute to conduct research on how different factors affect the employment, } \\
\text { rehabilitation, and disability program participation behavior of people with disabilities. }\end{array}$ & All people with disabilities \\
\hline SSA Affective Disorders Demonstration & $\begin{array}{l}\text { Demonstration to study the effectiveness of providing improved access to quality treatment } \\
\text { for affective disorders to DI beneficiaries who receive DI due to affective disorders. }\end{array}$ & $\begin{array}{l}\text { DI beneficiaries with a primary } \\
\text { diagnosis of affective disorder }\end{array}$ \\
\hline $\begin{array}{l}\text { Assistant Secretary for Planning and } \\
\text { Evaluation (ASPE) Study of Employment } \\
\text { Supports Used by Working People with } \\
\text { Disabilities }\end{array}$ & $\begin{array}{l}\text { This study, sponsored by the Office of the Assistant Secretary for Planning and Evaluation } \\
\text { (ASPE) within the Department of Health and Human Services (HHS), will collect qualitative } \\
\text { data about the supports and other factors that contribute to the employment of successfully } \\
\text { employed people with disabilities. }\end{array}$ & $\begin{array}{l}\text { People with disabilities who are } \\
\text { successfully employed }\end{array}$ \\
\hline
\end{tabular}




\section{References}

Livermore, G., D. Stapleton, M. Nowak, D. Wittenburg, E. Eiseman (2000). The Economics of Policies and Programs Affecting the Employment of People with Disabilities. Draft Report for the U.S. Department of Education, National Institute on Disability and Rehabilitation Research.

Stapleton, D., M. Fishman, G. Livermore, D. Wittenburg, A. Tucker, and S. Scrivner (1999). Policy Evaluation of the Overall Effects of Welfare Reform on SSA Programs: Final Report. Report prepared for the Social Security Administration (April 23, 1999). 

For more information about the Cornell RRTC contact:

Susanne M. Bruyère, Ph.D.

Project Director

Cornell University

106 ILR Extension Building

Ithaca, NY 14853-3901

tel (607) 255-7727

fax (607) 255-2763

tty (607) 255-2891

emailssmb23@cornell.edu

web www.ilr.cornell.edu/rrtc 